\title{
Cash Flow Volatility and Firm Investment Behaviour: Evidence from African Listed Firms
}

\author{
Edson Vengesai, Farai Kwenda \\ Economics and Finance, University of KwaZulu Natal, Durban, South Africa \\ vengesaie@gmail.com
}

\begin{abstract}
This study explored the association between cash flow variability and investment behaviour of African listed firms. The research employed a dynamic panel data model estimated with the difference and system Generalised Method of Moments estimation techniques on a panel of 815 listed African non-financial firms. The estimation techniques control for unobserved heterogeneity, endogeneity, autocorrelation, heteroscedasticity and dynamic panel bias. Two different measures of volatility were employed; the exponentially weighted moving average, a forward-looking measure that captures innovations in cash flow volatilities and the coefficient of variation that captures the mechanical effect of the possible relation between cash flow levels and volatility. The results obtained suggested that cash-flow volatility is associated with average lower investment in African firms. These findings show that not only cash flows are an important determinant of investment decisions, but the variability of the cash flows also has a significant bearing on the investment levels of African firms. Cash flow volatility has a significant negative impact on investment even for firms with higher cash flows and unconstrained firms. African firms should not only aim at achieving higher cash flows, but the stability of the cash flows is equally important to sustain solid investment levels.
\end{abstract}

Keywords: Cash flow Volatility, Investment, Generalised Method of Moments, Africa

\section{Introduction}

Cash flow is the lifeblood of any firm as is blood to the heart. Firms in Africa and other developing economies suffer unhealthy cash flow streams and liquidity challenges accentuating financial constraints. Cash flow shortages and volatility may propel budgets into disarray, deter capital expenditures, disrupt production, or delay debt repayments (Minton \& Schrand, 1999). Cash flow variation influences the firm's financial behaviour and financial commitments (da Costa Moraes, Nagano, \& Sobreiro, 2015). Low cash flows imply financial constraints and thus impacting on $t+$ he investment behaviour of such firms. As a result, it is essential to examine the effect of cash flows on investment given the inseparability interplay among these financial pillars. The effects of financial "constraints on firm behaviour and the manner in which firms perform financial management are central areas in corporate financial management. The Keynes school of thought argues that if a firm has unrestricted access to external capital, such a firm is financially unconstrained there is no urgency to safeguard against future investment needs.

The literature on the impact of financial constraints on the behaviour of firms has traditionally focused on corporate financial constraints and firms in developed economies. There is persistent behavioural and structural heterogeneity between firms in developing and developed economies, resulting in diverging economic and financial implications for firms' fundamentals. Financial constraints will vary with the availability of internal funds, rather than only with the availability of positive net present value projects (Minton and Schrand 1999). To the best of the researcher's knowledge little or no studies have been undertaken in the context of developing economies such as in Africa on whether cash flow volatility influences firms to time their investment decisions or should they decrease their investment (Amo Yartey, 2011). Accordingly, the need exists to examine the influence of financing friction on investment by comparing the empirical sensitivity of cash flow to investment across firms with evidence from Africa a developing economy." This study contributes in a number of ways to the literature on cash flow volatility and firm investment behaviour. First, the paper offers new evidence on cash flow volatility and firm investment behaviour in developing economies/markets.

The majority of the existing studies does not provide any developing market evidence, despite the fact that firms from developing markets are increasingly occupying a significant role in the world economy (Alfaro, Chanda, Kalemli-Ozcan, \& Sayek, 2004). Second, from a methodological perspective, the current research improves on previous work by utilising a dynamic panel data model and the two estimation techniques: the 
difference and system Generalised Methods of Moments (GMM) to control for heterogeneity and endogeneity. The results showed evidence that higher cash flow volatility is associated with average lower investment in African listed firms. Controlling for financial distress, the availability of internal funds and growth opportunities the volatility of cash flow remains a significant determinant of firm investment. Previous studies reveal that the level of cash flows determines the firm's investment power and ability (Donaldson, 1964; Myers and Majluf, 1984; Booth, 2006). These studies emphasised on the importance of high cash flows for firms. This study also contributes to the literature by exploring evidence on how the volatility of these cash flow impact on investment. Firm investment behaviour is not only dependent on the altitude but the stability of cash flow also has a significant bearing on discretionary investment. Firms should also pay attention to maintaining cash flow stability not only higher cash flows.

The rest of the article is structured as follows: Section two expounds the theoretical aspects of cash flow and firm investment; Section three describes the research design and methodology; Section four presents the results and findings; Section five explains the limitations of the study and areas for further research. Section six concludes this article with a number of concluding remarks.

\section{Cash Flow Volatility and Firm Investment Behaviour in Africa}

Cash flow stream is fundamental to investors, creditors, and rating agencies inter alia. Investors pay attention to cash flow for investment decision purposes, creditors are concerned with solvency decisions of the firms they extended credit to. Yuan and Motohashi (2014) explained that cash flow directly measures the operational ability of the firm to meet its day-to-day financial commitments. In conventional finance theory, the discounted value of all expected future cash flow theoretically equates to the intrinsic worth of a firm. Yun et al. (2015) posit that cash flow prediction is of essential value to investors, analysts and managers. Firms with more uncertainty in cash flow will be associated with more risk, calling for a higher discount rate yielding a lower firm value. In this regard, firms generating high and stable cash flow are regarded as more valuable than low cash flow firms. Most African firms are crippled with low cash flows coupled with high volatility in cash flow streams due to unstable economic and political environments (Monga \& Lin, 2015). African firms operate in extremely harsh and challenging environments with high levels of volatility, inadequate inputs, uncertain basic goods supply such as electricity and water (Bigsten \& Söderbom, 2006).

Monga and Lin (2015) highlighted that African firms face too much volatility in their cash flows mainly due to fluctuations in demand, irregular payments from customers, volatile operations and prices arising from unstable exchange rates and political atmosphere. Volatile operating environments in these economies raise the risk premium and increase the threshold return that is necessary on triggering investment, low real returns and volatile cash flows in African firm scares investors away, thereby lowering investment. Gwatidzo and Ojah (2009)) document that African financial markets are weak with limited long-term borrowing and lending. The limited credit supply affects the firms to expand the supply capacity derailing investment in African firms. Most African firms are trapped in a vicious cycle of stagnation. Firms in Africa are currently unable to hedge against currency and external fluctuations thereby creating more volatility on their operations and cash flows generating poor performance-limiting investment (Bigsten \& Söderbom, 2006). African firms are producing lower output levels which are leading to higher inefficiency levels (Monga \& Lin, 2015). Monga and Lin (2015) found that African firms face similar constraints (of limited access to credit, limited goods market and input shortages) compared with other developing countries in general, however the impact of the constraints different on African firms. Access to credit depends on firm size.

Small firms face numerous challenges in accessing funds (Bigsten \& Söderbom, 2006). Söderbom, Teal, and Wambugu (2005) found that two-thirds of the small firms appear to be credit constrained compared with $10 \%$ of large firms appearing to be credit- constrained. Most African economies are dominated by the informal small firms with limited access to credit drawing back investment. Investment is stagnant and insignificant, and the economies of these countries are not growing. The European Parliamentary Research Service (EPRS) reported economic stagnation in most countries in Sub-Saharan African (SSA) in the period 2000-2015 (Zamfir, 2016). The investment rate in Africa on average for the past two decades has hovered around $18 \%$ and was either unchanged or declining in a number of countries in Africa (UNCTAD, 2014). 
Firm Investment and Cash Flow Volatility: Considerable effort has been expended in analysing the linkage between uncertainty and investment at aggregate levels (Baum, Caglayan, and Talavera (2009). In literature, there are various sources of uncertainty that cause fluctuations in aggregate investment. A multiplicity of studies has analysed the impact of exchange rate fluctuations on aggregate investment and firm-level investment such as Goldberg (1993), Campa and Goldberg (1995), Darby, Hallett, Ireland, and Piscitelli (1999) and Servén (2003). Other studies found the impact of uncertainty from the output, interest rates, prices (Driver and Moreton (1991), Calcagnini and Saltari (2000), Ferderer (1993), Hurn and Wright (1994), Edmiston (2004). Using firm-level data several studies employed measures of uncertainty from the output, firm-specific liquidity, stock prices, the exchange rate on the firm-level investment. Ghosal and Loungani (2000) found a negative relationship between output and firm-level investment. Using stock return data, Leahy and Whited (1995) found a strong negative impact of stock return uncertainty on investment. Guiso and Parigi (1999) observed a negative correlation between demand uncertainty and capital accumulation. Beach et al. 2001 reported that uncertainties in the macroeconomic fundamental significantly affect investment. Bloom, Bond, and Van Reenen (2007) suggested that higher uncertainties reduce demand shocks effects on investment.

These studies examined the linkages of various uncertainties and sensitivities and investment at the aggregate and industry levels. An insignificant number of studies focused on the interaction between investment and cash flow uncertainties only in the developed economies. Studies that have been done focused more on cash flow levels. However, not only cash flow levels are deemed essential in investment decisions, but their volatility has a significant bearing on the firm's behaviour. Few studies that have been conducted on the volatility of cash flows were based on firms in developing economies. Up to the present no research has been conducted to analyse how firms behave in environments of cash flow volatilities in Africa and in developing nations. This article contributes to filling that gap. Numerous studies have analysed the relationship between cash flow levels and investment. In theory, firm investment should be unrelated to internally-generated cash flows (Modigliani \& Miller, 1958). The majority of empirical studies in developed economies, including Bates (2005), DeAngelo, DeAngelo, and Stulz (2004), Harford (1999), Jensen (1986) and (S. Fazzari, Ferri, \& Greenberg, 2008), (Carpenter, Fazzari, \& Petersen, 1998; S. M. Fazzari, Hubbard, Petersen, Blinder, \& Poterba, 1988) documented a positive relation between cash flow and investment, implying that firms with higher cash flows invest more.

However, the volatility of the cash flows has not gained substantial attention. Risk management theories suggest value-creating firms should maintain smooth cash flows (Froot, Scharfstein, \& Stein, 1993). In the context of risk management, A. Shapiro and S. Titman (1986), Lessard and Lightstone (1990), Geczy, Minton, and Schrand (1997) and Tufano (1996) found that firms active in risk management have more benefits from reducing cash flow sensitivity. They argue that firms that can smoothen their cash flow reduce costs from external financing and subsequently add value to the firm. This result has two key implications for this study, first explaining the negative relationship between cash flows and investment and second, emphasizing on the negative impact of cash flows on investment and value of the firm. Minton and Scharand (1999), using United States of America (USA) firms, confirms that cash flow volatility increases the need for external financing and increases the cost associated with internal financing which, in turn, affects a firm's investment policy. Riddick and Whited (2009) suggest that in financing future investment needs firms to trade off the benefits of generating internal funds and the costs of holding cash.

This analysis showed that internal funds are valuable to a firm's investment and financing. The availability of internal funds determines the decision to seek external funding. This should then imply that the volatility of the internally- generated funds will influence the stability of investment and firm value as well. The analysis of Riddick and Whited (2009) indirectly suggested a negative relationship between cash flow volatility and investment using data from firms in the USA. Minton et al. (1999), found a negative association between investment and volatility in cash flow, implying that firms experiencing lower cash flow forego investment opportunities without accessing external capital markets. Minton et al. (1999) estimated the standard investment equation with the Ordinary Least Squares (OLS) technique. This technique may have problems on heterogeneity and endogeneity issues from measurement errors and the possibility that Tobin's $Q$ in the model might be an endogenous variable (Muñoz, 2013).The study of Allayannis and Weston (2003) on 
earnings volatility, cash flow volatility and firm value on Comp Stat firms, found evidence that investors negatively value the volatility in cash flow.

They also found a negative relationship between cash flow volatility and investment opportunities, as measured by Tobin's $Q$. This was not an indirect measure of volatility on cash flow and investment, however, investment is highly related to value if positive net present value projects are taken into account. Thus, factors that affect value should also affect investment, from this analysis it is also expected that investment will negatively correlate with cash flow volatility as firm value. Fazzari et al. (1988) documented that "the sensitivity of cash flows should be higher for financially constrained firms. This brings in internal and external financing. Kovacs (2005) suggested that firms rely on external financial markets when there are low informational asymmetries. Almeida, Campello, and Weisbach (2004) indicated that non-constrained firms have less cash to cash flow volatility compared to constrained firms. Acharya and Schaefer (2006), developing the concept from Almeida's (2004) idea, added investment opportunities and found an inverse relationship. Considering the elements of corporate cash holdings, Ferreira and Vilela (2004) found that firms with more investment opportunities hold more cash and generate higher cash flows than firms with lower investment opportunities."

Using data from firms in the USA, Booth and Cleary (2006) on analysing cash flow volatility financial slack and investment decisions in the presence of market imperfections, found less correlation between investment and cash flows owing to the construction of a financial slack and strengthening balance sheet by firms should they anticipate any shortages, resulting in less effect on the investment outlays. They suggested that the higher the volatility of cash flows, the higher the level of financial slack and consequently resulting in less sensitivity to cash flows. However, this finding is inconclusive on whether these firms increased or decreased their investment levels in being less sensitive." Donaldson (1963), based on the separation of firm ownership and management justified a financial hierarchy. Myers and Majluf (1984) concurred with the financing hierarchy basing on informational asymmetry, when managers have insider information. These studies indicate that a financing hierarchy restricts investment to internally generated cash flows due to risk aversions. The financial hierarchy caused by an agency or informational asymmetry, implied financial constraints which will, in turn, affect the firm's investment. If the firm is restricted to internal cash flows, the volatility of such cash flows poses a major risk to the firm's investments.

Gilchrist and Himmelberg (1995), found higher investment-cash flow volatility in respect of small firms than large firms. Small firms face greater agency costs and informational asymmetries resulting in more financial constraints. Cleary (2006) found that large firms have more cash flow sensitivity than small firms." Booth and Cleary (2006)), found that the uncertainty in the firm's cash flows introduces uncertainty in the investment present values. Investment value increases monotonically at a decreasing rate in cash flows (Booth and Cleary, 2006). Increases in cash flow increase the ability of a firm to undertake investments. In modelling the Net Present Value (NPV) function, Booth, Aivazian, Demirguc-Kunt, and Maksimovic (2001) documented that as the volatility of cash flows increases with a reduction in future cash flows, the volatility of financial slack increases. The increase in financial slack will, therefore, imply a reduction in available funds for investment purposes, thereby lowering investment. There is a value to financial slacks from the internal and external financing wedge (Booth and Cleary, 2006).

They suggested that firms with more volatile cash flows experience more value in adding financial slack, since they experience the greatest wedge between internal and external capital. Such firms with more financial slacks have less correlations between their investments and cash flows. Firms with stable and less sensitive cash flows will have a small external and internal capital wedge which will see little value in financial slack. Such firms increase their debt and have more sensitive investment ratios to cash flow. However, the models were estimated with the fixed- effects estimators which cannot account for Nickel bias and the endogeneity issues, an estimator that is capable of controlling for such biases may yield better results." This study provides the first and direct evidence of the association between firm investment behaviour and the volatility of cash flows in Africa and complements the findings of the indirect tests from the developed economies using a dynamic panel data model as developed by Arellano and Bond (1991) with the GMM estimation technique to cater for endogeneity and heterogeneity using evidence from African firms and contributing to the existing body of financial literature in this respect." 
Hypotheses: In light of the empirical literature and the contexts of African firms, expectations regarding firm investment behaviour were:

H1: Cash flow volatility (CFV) has a negative effect on the current investment of African firms.

H2: the effect of cash flow volatility on investment is heterogeneous by financial constraints.

H3: There is a positive relationship between growth opportunities and Investment.

H4: There is a positive relationship between sales and investment.

\section{Empirical Approach}

The study hypothesised a negative association between firm investment and volatility of cash flows. The relationship was tested following (Carpenter \& Guariglia, 2008; B. A. Minton \& C. Schrand, 1999). The study extended Carpenter and Guariglia (2008) and B. A. Minton and C. Schrand (1999) model to a dynamic panel model estimated in levels and in first differences to eliminate unobservable heterogeneity with two-step GMM estimators in an unbalanced panel data of African listed firms, from 1996 to 2015.

Data and the Variables: The research considered 1074 non-financial firms listed on all African stock exchanges as given on the Bloomberg online financial database. All African non-financial firms were selected to avoid selection bias. Listed firms were specifically selected because of the availability of reliable financial data. In constructing the sample, financial firms were excluded because of the complexities in their capital structure nature, their capital structures are regulated (Akhtar \& Oliver, 2009) and their financial strategies are different from the context of the study. The estimation techniques used require estimation of equations in first differences and lagging of regressors twice or more. To allow for the instrumentation processes and first differencing at least three cross-sectional observations are needed, firms with at least 4-year financial reported data were kept. The final sample remaining for estimation comprises 815 firms from 22 stock exchanges for a period of 20 years (1996-2015) the period allowed for the collection of complete and audited data reported by the time of data collection. The study employed an unbalanced panel data of 16300 observations after checking and screening for apparent coding errors and missing variables. Panel data enables the observation of multiple phenomena over many periods of time and the ability to reduce colinearity in explanatory variables, improving the efficiency of econometric estimates (Akhtar, 2005).

Measures of Cash Flow and Cash Flow Volatility: Volatility is a widely used measure of risk in financial markets. In this regard, volatility can either be historical (observed over time) or implied (predicted from market data) (Guo, 2012). The assumption in terms of a historical volatility measure is that the past is prologue, the historical trend is measured hoping that it is predictive. In this regard, the implied volatility observes at the volatility implied by the market and ignores history (Guo, 2012). This study focused on historical volatility since historical cash flows observed by African firms over the past periods as given in the financial statements were used.

Figure 1: Measures of Volatility

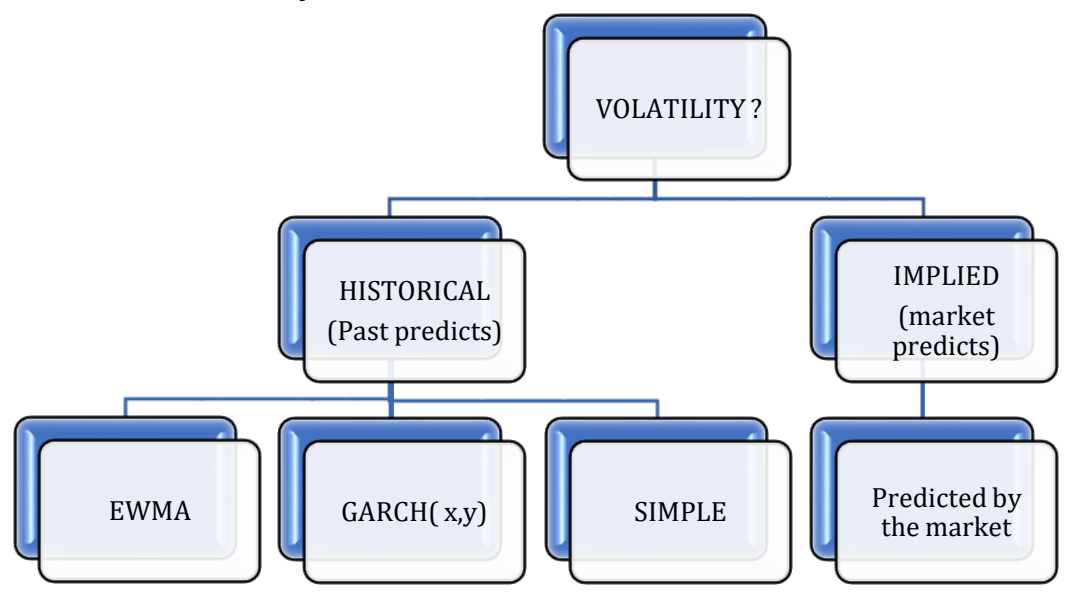


As shown in Figure 1, historical volatility can be estimated in three ways, namely simple volatility, exponentially weighted moving average (EWMA) and the Generalised Autoregressive conditional heteroskedasticity, GARCH (x,y) approach. Following financial literature (Minton et al., 1999) simple volatility as measured by the coefficient of variation of cash flows was used and the EWMA measure for robustness checks.

Coefficient of Variation of Cash Flows (CVCF): The first measure was defined as the coefficient of variation in a firm's operating cash flow over the period preceding each of the sample years (Guoming, 2009). In this respect, for the year 2015, the coefficient of variation was computed with 19-year data from 1996 up to 2014 and for 2014 it will be 18-year data from 1996-2013 and so forth. The coefficient of variation accounts for the size of the firm's cash flows as well as the volatility thereof Booth (2006). The coefficient of variation also reduces the mechanical relationship between volatility and cash flow levels (Minton, A, B. \& Schrand, C. 1999). However, this measure may result in serial correlation from the calculation of the standard deviation over time. A dynamic panel data model and the estimation technique are robust in dealing with autocorrelation. Cash flow from operations was obtained from the firms reported statements through the Bloomberg financial database, measured as the sum of earnings before extraordinary items and depreciation (Net income add back non-cash charges, adjusted for working capital changes).

The coefficient of variation was estimated as:

$$
\frac{\sigma_{O P C F_{i, t}}}{\mu_{i, t}}
$$

Where: $\sigma_{O P C F_{i, t}}$ is the standard deviation of operating cash flows for each firm. $C F_{i}$ is the firm's cash flow. $\mu_{i, t}$ is the expected value of the realised cash flows for each financial reporting period. The expected value $\mu_{i, t}$ was calculated as the simple average of all cash flows in each financial reporting period for the 20 -year period. To estimate the standard deviation, the previous $n$ observations in cash flows were used to estimate an unbiased estimator of variance, then the standard deviation of cash flows was estimated as the square root of the variance as follows;

$$
\sigma=\sqrt{\frac{\sum_{1=1}^{n}\left(O C F_{i, t}-\in(O C F)\right)^{2}}{n-1}}
$$

$\sigma$ is the standard deviation of operating cash flows $\left(O C F_{i, t}\right) . \mu=\in(O C F)$ is the mean of operating cash flows calculated as the arithmetic average of the observations for each year from 1996 to 2015 for the respective period.

Exponentially Weighted Moving Average (EWMA): The standard deviation of cash flows over time may fall short in the sense that it may give rise to substantial serial correlation and also all observations are similarly weighted, the technique cannot mimic volatility clustering. In this regard, a more sophisticated different technique, the EWMA, a particular case of the GARCH model was employed, which has the ability to mimic volatility clustering normally found in financial series for the robustness of the results. The EWMA is forwardlooking in nature and it predicts the innovations in volatility by weighing more recent levels and considers the fact that recent changes in cash flow levels are more relevant. This approach provided a more representative measure of the perceived volatility and it also enables forecasting of future levels of variances. The EWMA considers that volatility is persistent and tends to cluster. Particularly higher volatility periods tend to be followed by higher volatility periods and lower volatility is followed by periods of lower volatility (Taylor, 2004).

The EWMA is a special form of the ARCH (m) model developed by Engle (1994) given by,

$$
\sigma_{n}^{2}=\omega+\sum_{i=1}^{m} \alpha_{i} x r_{t-i}^{2}
$$

Where, $\alpha_{i}$ is an observations weight i days ago, $\alpha_{i}>0$ and $\sum_{i=1}^{m} \alpha_{i}=1$, The weight of $\alpha_{i}$ decreases exponentially backwards in time such that;

$$
\alpha_{i+1}=\lambda \alpha_{i}=\lambda^{2} \alpha_{i-1}=\cdots \lambda^{n+1} \alpha_{i-t}
$$

The some of the weights are applied such that they equal the unity constraint, it follows that; 
For $\lambda<1$, then $\alpha_{i}=1-\lambda$

$$
\sum_{i=1}^{\infty} \alpha_{i}=\alpha_{i} \sum_{i=1}^{\infty} \lambda^{i}=1
$$

It follows that for $\sigma_{t-1}^{2}$ estimate:

$$
\sigma_{t-1}^{2}=\sum_{i=1}^{n-1} \alpha_{i} r_{t-i-1}^{2}=\alpha_{1} r_{t-2}^{2}+\lambda \alpha_{1} r_{t-3}^{2}+\cdots \lambda^{t-3} \alpha_{1} r^{2}
$$

The volatility at period $t\left(\sigma^{2}{ }_{t}\right)$ is estimated as follows;

$$
\sigma_{t}^{2}=(1-\lambda) r_{t-1}^{2}+\lambda \sigma^{2}{ }_{t-1}
$$

More generally the EWMA model used to estimate volatility takes the following form:

$$
\sigma^{2}{ }_{t}=(1-\lambda) \epsilon^{2}{ }_{t-1}+\lambda \sigma^{2}{ }_{t-1}
$$

Where $\sigma^{2}{ }_{t}$ the current volatility at period t is, $\sigma^{2}{ }_{t-1}$ is the volatility for the previous period (t-1), $\epsilon_{t-1}{ }_{t-1}$ is the cash flow mean for the prior period. $\lambda$ Take the value 0.94 as given by the Taylor, (2004).

Descriptive Statistics: Table 1 shows the descriptive statistics of investment, cash flows and the control variables. There is more variation on realised cash flow volatility (CFV) measured by the coefficient of variation of cash flows as shown by a very high standard deviation (114.16) relative to the mean which is 2.36. $\mathrm{n}$ of cash flow volatility CFV2 measured by the EWMA has less variation (as it reported a standard deviation of 0.3512) compared to the CFV. The less variation is a result of the smoothing effect of the calculation methodology. The variation in cash flows in Africa can be explained by uncertainties in the business cycle operating environment, economic instability, technological hindrances and political unrest. The descriptive statistics also show that there is a high variation of cash flows the standard deviation of cash flow (0.1218) is one-and-half times above the mean (0.1009) indicating the high variation of cash flows among African firms.

Table 1

\begin{tabular}{lllllll}
\hline Variable & Description & Mean & SD & $\mathbf{2 5 \%}$ & Median & $\mathbf{7 5 \%}$ \\
\hline CFV2 & Cash flow volatility EWMA & 0.2595 & 0.3512 & 0.0411 & 0.1273 & 0.3236 \\
CFV & Cash flow volatility CV & 2.3631 & 114.1612 & 0.1280 & 0.3734 & 0.8084 \\
INVSTNET & Tangible Investment & 0.2217 & 0.2599 & 0.0617 & 0.1517 & 0.2931 \\
OPCF $^{2}{ }_{i, \boldsymbol{c}, \boldsymbol{t}}$ & Operating Cash flow & 0.1009 & 0.1218 & 0.0328 & 0.0959 & 0.1757 \\
CF2 $_{\text {CFXCFV2 }}$ & Operating Cash flow square & .02690 & 0.0420 & 0.0025 & 0.0109 & 0.0322 \\
CFSHORT & Cash flow sensitivity of cash & 0.0234 & 0.0536 & 0.0014 & 0.0087 & 0.2818 \\
CFEXCESS & Cash shortages & -0.2986 & 0.6850 & -0.3085 & -0.1321 & -0.0155 \\
SALE & Cash excess & 0.0395 & 0.2766 & 0.0000 & 0.0000 & 0.0000 \\
$\mathbf{Q}$ & Sales & 1.0941 & 0.7275 & 0.5847 & 0.9544 & 1.4174 \\
Leverage B & Growth opportunities & 1.5070 & 0.8056 & 0.9498 & 1.2512 & 1.8096 \\
Non distress & Leverage (long term debt) & 0.1220 & 0.1220 & 0.0258 & 0.0855 & 0.1775 \\
High growth B & High growth firms & 0.2073 & 0.3155 & 0.0094 & 0.0835 & 0.2468 \\
Sourtressed firms & 0.2489 & 0.3328 & 0.0408 & 0.1232 & 0.3105
\end{tabular}

Source: Authors calculations based on data obtained from Bloomberg

The table provides descriptive statistics of dependent and the explanatory variables of the sample firms for the 20-year period between 1996 to 2015 for listed African firms.

Correlation Analysis: Table 2 reports the correlation matrix of the response variables and investment. The correlations are included to check for multicollinearity. A correlation above 0.8 between independent variables is an indication of the presence of multicollinearity. From the table above, the highest correlation is 0.37 between cash flows and Tobin's Q. All the values are below 0.5 which proves the absence of 
multicollinearity among the independent variables. The correlation table also pre-evidenced a negative correlation between investment and cash flow volatility for all measures of cash flow volatility. There is a statistically significant negative correlation between investment and cash flow volatility. Firms with too volatile cash flows tend to invest less. There is a statistically significant negative relationship between cash flow shortages and investment and a positive relationship between excess cash and investment as shown on the correlation matrix in table two. African firms experiencing cash flow shortages have less investment ratios and firms with excess cash flow invest more. There is a significant negative correlation between cash flow volatility and operating cash flows. Sales and growth opportunities as expected have a positive relationship with investment.

Table 2: Correlation Matrix

\begin{tabular}{llllllll}
\hline & Investment & CFV2 & CFV & CF & CF SHORT & CFEXCESS & SALE \\
\hline Investment & 1 & & & & & & \\
CFV2 & $-0.055^{*}$ & 1 & & & & \\
CFV & 0.0001 & & & & & \\
& -0.0144 & -0.0009 & 1 & & & \\
CF & 0.2976 & 0.9449 & & & & \\
& $0.1865^{*}$ & $-0.1347^{*}$ & -0.0141 & 1 & & \\
CFSHORT & 0.0000 & 0.000 & 0.2947 & & & \\
& $-0.179^{*}$ & $-0.0352^{*}$ & 0.0037 & $-0.060^{*}$ & 1 & & \\
CFEXCESS & 0.0000 & 0.0078 & 0.7854 & 0.0000 & & & \\
& $0.0618^{*}$ & $0.0358^{*}$ & -0.0035 & $-0.059^{*}$ & $0.0623^{*}$ & 1 & \\
SALE & 0.0000 & 0.0068 & 0.7951 & 0.0000 & 0.0000 & & \\
& $0.2033^{*}$ & 0.0009 & -0.014 & $0.1401^{*}$ & $-0.1542^{*}$ & 0.0037 & \\
Tobin Q & 0.0000 & 0.9444 & 0.2804 & 0.0000 & 0.0000 & 0.0541 & \\
& $0.1827^{*}$ & $-0.0708^{*}$ & -0.0174 & $0.3543^{*}$ & $0.1178^{*}$ & -0.0027 & $0.1154^{*}$ \\
& 0.0000 & 0.0000 & 0.196 & 0.0000 & 0.0000 & 0.0894 & 0.0000 \\
\hline
\end{tabular}

Source: Own calculations based on sample data

CFV cash flow volatility EWMA measure CFV volatility measured by the coefficient of variation, CF operating cash flows * statistically significance.

Figure 2: Cash Flow Volatility (CFCV) and Investment Trend in African Listed Firms

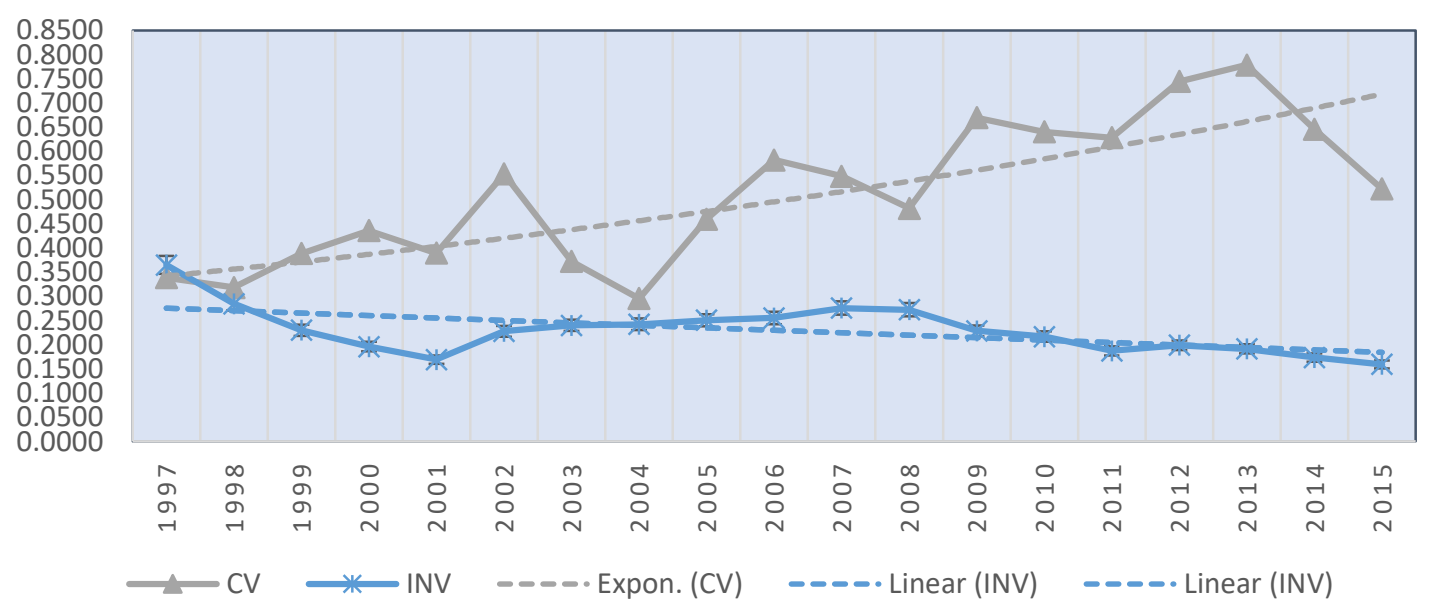

Source: Bloomberg online database 
Figure 2 shows investment and cash flow volatility trends of listed African non-financial firms for the period 1996-2015. Cash flow volatility measured by the coefficient of variation of cash flows (CV). The trend reveals a notable decline in investment levels over the period as shown by the negative gradient on the trend line. The evolution of cash flow volatility is random depicting a stochastic trend. The random trend in cash flow volatility is associated with a decline in investment and cash flow levels. It can be noted from Figure 2 that the levels of volatility and the trend is increasing over time associated with a gentle decline in cash flows and investment levels. The figure shows that from 1996 investment levels in Africa were declining until 2000, from then there was a notable constant increase in investment levels for the period 2002-2007. This was reported to be due to the effects of globalisation, new foreign direct investment, capital injection and adoption of new technologies in Africa which have seen the region being the highest destination of FDI during this period. A notable decline from 2008 can be explained by the global financial crises. Since then African firms' investments have not yet recovered from the financial crisis effects coupled with other regions' peculiar effects as shown by a declining trend in investment.

Model Specification: To examine the relationship between cash flow volatility and investment extended Lang et al. (1996) and Minton, A, B. and Schrand C. (1999) investment model was extended to a dynamic panel data model which enables the observation of multiple phenomena obtained over multiple time periods for the same firms and countries. Given that investment trends are dynamic, current levels of investment are driven by past investments. Firms generally want to smoothen their investment pattern (Aivazian, Ge \& Qiu, 2005) as their past behaviour influences current behaviour. Lagging the investments variable helps to examine the impact of previous investment trends on current investment levels. A lagged dependent variable reduces autocorrelation that may arise from any misspecification (Arellano \& Bond, 1991). Investment dynamics over time are captured, and the estimation method deals with endogeneity problems and Nickell bias in fixed effects. A dynamic model also allows partial adjustment mechanism modelling (Baum, Barkoulas, \& Caglayan, 2001).

Consider a dynamic model, which caters for individual effects, as given by

$$
y_{i, t}=\gamma y_{i, t-1}+x_{i t} \beta+\eta_{i}+\varepsilon_{i, t} ;|\gamma|<1
$$

where $\eta_{i}$ is a fixed effect, $x_{i t}$ is a vector of explanatory variables with $\mathrm{k}$ factors $(\mathrm{k}=1 \ldots, 4) \cdot \varepsilon_{i, t} \sim \mathrm{N}\left(0, \sigma^{2}{ }_{\varepsilon}\right)$ is a random disturbance and assuming $\sigma_{\varepsilon}^{2}>0, \in\left(\varepsilon_{i, t}, \varepsilon_{j, s}\right)=0$

Lang et al., (1996) and B. Minton, A, and C. Schrand (1999) standard investment model were extended to a dynamic panel fixed model which includes a fixed effects parameter to cater for individual firms and country's effects as shown by Judson and Owen (1999). The specific model estimated takes the following form;

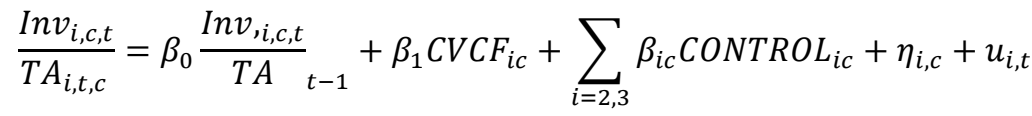

$\operatorname{Inv}_{\mathrm{i}, \mathrm{c}, \mathrm{t}}$ is a proxy for firm investment scaled by the firm's total assets (TA) to do away with the effect of size and diverging figures. CVCF is the coefficient of variation of cash flow the proxy for cash flow volatility. CONTROL $_{\text {ic }}$ Are the control variables/other explanatory variables that explain a firm's investment behaviour, $\eta_{\mathrm{i}}$ is time invariant unobservable specific effect and $u_{i, t}$ is the error term. Fixed effects at the firm and country level $\eta_{\mathrm{i}}$ was included also which captures firm-specific characteristics and business-cycle effects inherent to each country. $\beta_{1} / \beta_{\text {ic }}$ are the coefficients of the model to be estimated. The control variables (CONTROL) are Tobin's $Q$ and sales growth that measure growth. Fazzari et al. (1988) categorise sales growth as a significant determinant of CAPEX. Sales growth is measured for the 20-year rolling period as volatility as average annual change in sales divided by beginning of period sales. Tobin's $Q$ was measured as the firm's market to book value ratio.

Estimation Technique: In "light of the view that corporate finance studies exhibit uppermost levels of serial correlation and endogeneity as a result of multiple independent variables (Mark \& Hankins, 2012), there is a need for an estimation technique that deals with this problem. Previous studies including Minton and Schrand (1999) assumed non-unobservable individual effects and used a pooling regression. The pooling method is inefficient given that $\mu_{i}$ is not directly observable and it correlates with other explanatory variables (Antoniou, Guney, \& Paudyal, 2008). Even if we take first differences of the variables to eliminate 
the time invariant fixed effects, OLS will still be inefficient due to the correlation of $\Delta \operatorname{In} v_{i, t}\left(\operatorname{In} v_{i, t}-\operatorname{In} v_{i, t-1}\right)$ and $\Delta \varepsilon_{i, t}\left(e_{i, t}-e_{i, t-1}\right)$. There is also high heterogeneity across firms, noting that we extended to a panel of numerous countries, heterogeneity is inevitable. Some studies used a fixed effects estimator. A fixed effects estimator, however, cannot control for endogeneity problems, which can be controlled by using the instrumental variables (IV) technique.

Nevertheless, the Anderson and Hsiao (1982) IV technique might not be efficient since it does not use all the available moment conditions and the difficulties in identifying the instruments. Muñoz (2013) highlighted that the endogeneity problem arises from possible measurement errors, omitted variables, possible bidirectional causation and the presence of endogenous variables such as Tobin's Q. This results in the explanatory variables being correlated with the error term. The introduction of a lagged investment variable as an explanatory variable in equation 9 introduces autocorrelation with the error term, a dynamic bias that cannot be controlled by the IV and the traditional techniques. In such a model, there is a need to introduce stochastic variation into the model. Given endogenous explanatory variables, the presence of heteroscedasticity and serial correlation from idiosyncratic disturbances are beyond fixed effects. The system GMM attests to it being the suitable technique in such conditions (Roodman, 2006). System GMM enhances efficiency by employing additional instruments of the lagged first difference variable $\left(\operatorname{In} v_{t-1}\right)$. This solves the problem of weak instruments with difference GMM.

The technique instruments levels equations with first differenced instruments and instruments differenced equations with levels instruments generating a system of equations. The second equation provides additional instruments and increases efficiency (Blundell \& Bond, 1998). Level and lagged endogenous instruments make endogenous variables predetermined and not correlated with the error term. Variations among firms are also partially retained (Antoniou et al., 2008).

$u_{i, t}$ in equation 10 consists of country unobservable effects $v_{i}$ and specific errors $e_{i, t}$

$$
u_{i, t}=v_{i}+e_{i, t}
$$

Through first differencing equation 10 is transformed, to

$$
\Delta \operatorname{Inv} v_{i t}=\beta_{0} \Delta \operatorname{Inv} v_{i, t-1}+\beta_{1} \Delta C V C F_{i t}+\beta_{2} \Delta X_{i, t}+\Delta u_{i, t}
$$

The country fixed effect does not vary over time and by differencing the regressors it is removed, and equation 11 becomes:

$$
\begin{aligned}
& \Delta u_{i, t}=\Delta v_{i}+\Delta e_{i, t} \\
& u_{i, t}-u_{i, t-1}=\left(v_{i}-v_{i}\right)+\left(e_{i, t}-e_{i, t-1}\right)=e_{i, t}-e_{i, t-1}
\end{aligned}
$$

The presence of $\operatorname{In} v_{i, t-1}$ is a source of autocorrelation, which is controlled by instrumentation with past levels and differenced instruments in system GMM.

Additional Tests: The two-step system GMM technique developed by Blundell and Bond (1998) was employed to estimate the model. The utilisation of the orthogonal conditions on the variance-covariance capacitates control for the correlation of errors over time, heteroscedasticity in firms and simultaneity (Antoniou et al., 2008) and the ability to address the problems of endogeneity. Under these considerations, Blundell and Bond established that the system-GMM estimator becomes a handy tool. To obtain robust results, the study also controlled for the potential relationship between investment and cash flows and cash flow excess and shortages. To test "the impact of cash flow shortages and excess on investment firms were apportioned based on cash flows levels. In accordance with B. A. Minton and C. Schrand (1999), low cash flow firms were considered based on the difference between a firm's operating cash flows for time $t$ and its average historical cash flows for the cumulative periods. A negative figure indicates a shortfall position and a positive one will be an excess position. Cash flows variables controls for the observed sensitivity of investments to cash flow levels as documented by (Fazzari et al., 1998), Cleary et al. (1991) and KZ (1997). To control for the potential relationship between investment and cash flow levels. 
The following specification was used extending from equation 10.

$$
\begin{aligned}
\operatorname{Inv}=\beta_{0} \frac{\operatorname{Inv} i c}{T A}_{t-1} & +\alpha_{i}+c_{1} \frac{O P C F_{i, c}}{T A_{i, t, c}}+C_{2} O P C F_{i, c}^{2}+c_{3} C V C F+c_{4} C V C F_{i, c, t} * O P C F_{i, c} \\
& +\sum_{i=5,6} c_{i} \operatorname{CONTROL}_{i}+e_{i} .
\end{aligned}
$$

$\mathrm{OPCF}_{\mathrm{i}, \mathrm{c}}^{2}$ is the square of the operating cash flow value, $\mathrm{C}_{2}, \mathrm{C}_{3}, \mathrm{C}_{\mathrm{i}}$ are regression coefficients to be estimated. $\mathrm{CVCF}_{\mathrm{i}, \mathrm{c}, \mathrm{t}}$ is coefficient of variation of cash flows as defined in equation 1 times operating cash flows. Equation 15includes a continuous measure of firm-adjusted annual operating cash flow $\left(\frac{\mathrm{OPCF}_{\mathrm{i}, \mathrm{c}}}{\mathrm{TA}_{\mathrm{i}, \mathrm{c}, \mathrm{c}}}\right) \mathrm{OPCF}^{2}$ is the square of operating cash flows which controls for probable nonlinearities on the relation between operating cash flows and investment (B. Minton, A, \& C. Schrand, 1999). CVCF*OPCF is the interaction between the coefficient of variation of cash flows and operating cash flows which measure the impact of a firm's cash flow level on the estimated sensitivity of investment to cash flow volatility.

Cash Flow Volatility and Growth Opportunities: High growth firms are theoretically known for high retention levels associated with high investment levels (Kester, 1984). The cash flows of such firms are expected to vary more since they are still in the growth phase and they have higher risks from numerous investment opportunities they may undertake. Impact of cash flow volatility on high growth firms was also examined. Firms were also separated into high and low growth firms. Following financial literature, high growth firms were defined as those firms with Tobin's $Q$ greater than 1 (Aivazian et al., 2005). Firms with Tobin's $Q>1$ have more investment opportunities, higher market values and may generate higher cash flows from their profitable investment prospects. Their cash flows are different from low growth firms with no growth opportunities. This analysis will enable the researchers to determine if the effect of cash flow volatility is not influenced by the growth opportunities firm encounter. To examine the variances on the impact of cash flow volatility on high- and low-growth opportunity firms.

The researchers followed Aivazian et al. (2005). Extending from equation 9 to include a dummy variable for high- and low-growth firms to interact with cash flow volatility the following model was examined.

$$
\frac{I n v_{i c}}{T A}=\beta_{0}{\frac{I n v_{i c}}{T A}}_{t-1}+\alpha_{c, t}+\beta_{1} C V C F_{i c}+\beta_{1} \oint * C V C F_{i c} \sum_{i=2,3} \beta_{i c} C_{\text {ONTROL }}+e_{i c}
$$

Where, $\oint$ is a dummy variable $=1$ if Tobin's $Q>1$, and 0 if Tobin's $Q$ is $<1$. $\oint{ }^{*}$ CFVF has been added to the regression, for firms with Tobin's $Q>1$, the coefficient for volatility will be $\beta_{1}+\beta_{2}$. CONTROL $L_{i c}$ is a vector of other control variables that explains investment including size and growth opportunities.

\section{Empirical Results}

Regression Results: Table 3 presents the regression output of the investment model given in Equation 10 . Two GMM estimation techniques were used to estimate the model: the two-step difference and system GMM with orthogonal deviations option which handles unbalanced panel data. Two measures of volatility were used, the coefficient of variation on the historic cash flows and the EWMA technique. The coefficient of variation reduces the mechanical relationship between volatility and cash flow levels. The EWMA predicts the innovations in volatility by weighing more recent levels and considers the fact that recent changes in cash flow levels are more relevant. System GMM uses the levels equation together with the AB type orthogonally conditions to obtain a system of equations in levels and the other differenced. The second equation provides additional instruments and increases efficiency (Blundell \& Bond, 1998). Instruments for orthogonal deviations equations used were: for standard forward orthogonal deviations (FOD) Cash flow volatility and time dummies, for the GMM type (those assumed to be endogenous) investment, CFXCFV, Tobin Q sales were used. For the levels equations, cash flows and cash flow volatility were used as additional instruments to the orthogonal equation instruments. The coefficients of $C F V 2_{i, c, t}$ (EWMA) and $C F V_{i, c, t}$ (coefficient of variation of cash flows) were found to be negative and statistically significant at one percent significance level. These results provided evidence that there is a negative relationship between cash flow volatility and investment at a ninety per cent confidence level. Variation of cash flows has a significant adverse effect on investment in 
African firms. This is in accordance with risk management theories which suggest that smooth cash flows create value for firms (Froot et al., 1993).

Table 3: Dynamic Panel-Data Estimation, Cash Flow Volatility and Firm Investment

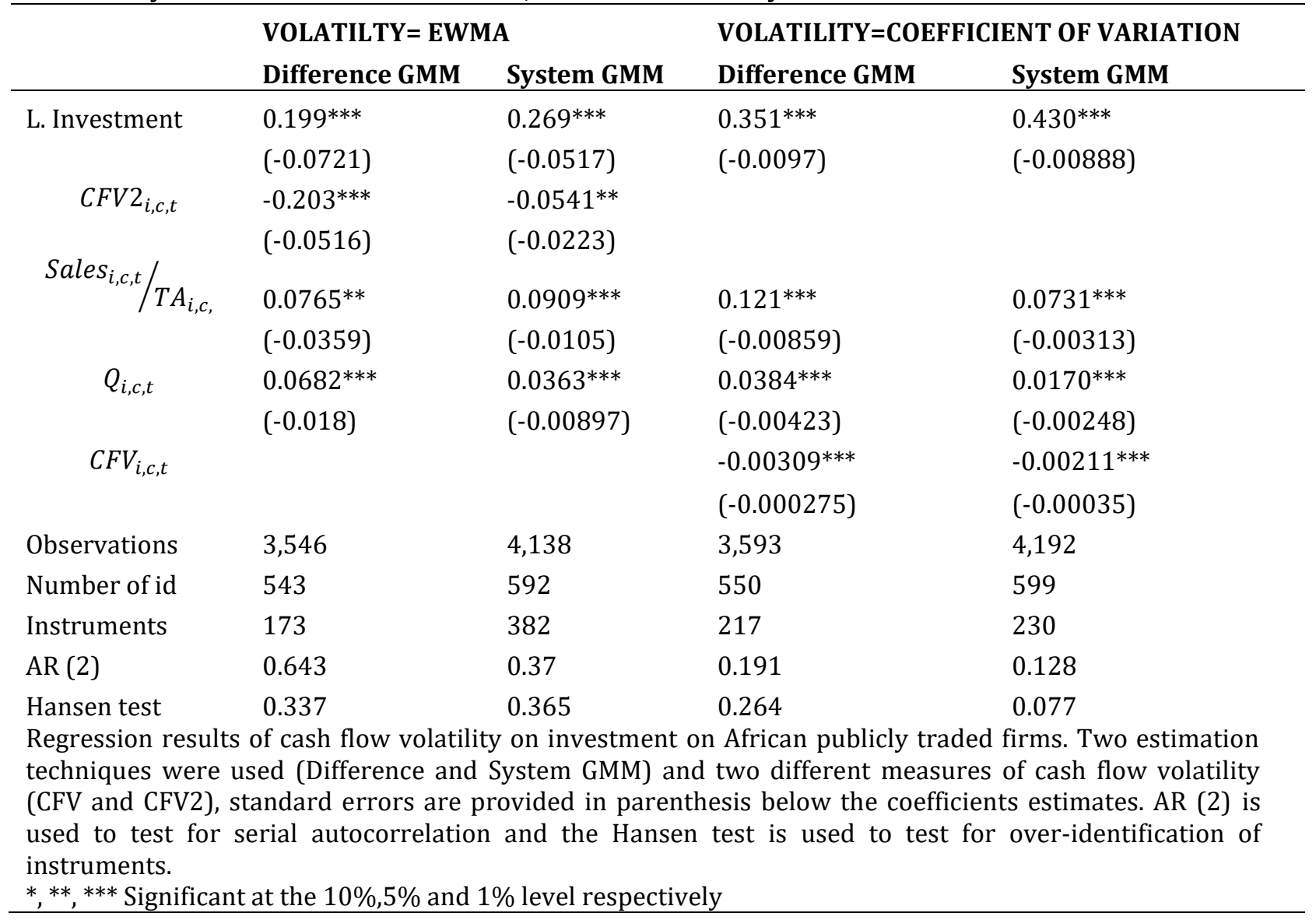

From the risk management theories perspective, firms that can smoothen their cash flow reduce costs from external financing which can add value to the firm. B. A. Minton and C. Schrand (1999) confirmed that cash flow volatility increases the need for external financing and increases the cost associated with internal financing, affecting a firm's investment policy. A. C. Shapiro and S. Titman (1986), Lessard and Lightstone (1990), Géczy, Minton, and Schrand (1997), Tufano (1996), in the context of risk management, found that active firms in risk management derive more benefits from reducing cash flow sensitivity. Firms experiencing high volatility in cash flows will experience higher financing costs lowering the NPV of its investments. As a result, cash flow stability is valuable to a firm's investment. From the perspective of cash holding and cash sensitivity, Opler, Pinkowitz, Stulz, and Williamson (1999), showed that firms with higher cash flows result in higher cash holdings and the volatility in cash flows will lead to higher precautionary needs and increase cash holdings. In this regard, an increase in cash holdings would mean a reduction in investment since cash holding and investment are not interdependent decisions. More cash holdings will mean less investment so if cash flow volatility leads to more cash holding then a reduction in investment will result.

The results are consistent with Minton (1999) in USA firms who found that volatility is associated with the lower investment. Indirectly, Allayannis and Weston (2003) on the study on earnings volatility, cash flow volatility and firm value on firms on Compustat found evidence that investors negatively value the volatility in cash flow and a negative relation between cash flow volatility and investment opportunities, as measured by Tobin's $Q$. Since investors value the volatility of cash flows negatively, this will reduce liquidity, increase the cost of accessing external finance and negatively impacting on firm investment. By using firms in the 
United States of America, Booth and Sean Cleary (2006) analysed cash flow volatility, financial slack and investment decisions in the presence of market imperfections which causes distinctions in internal and external financing. They found less correlation between investment and cash flows owing to the construction of a financial slack and strengthening balance sheets by firms should they anticipate any shortages. This will exert less effect on the investment outlays.

Economic Impact of Regression Results: Table 4reports the economic impacts of cash flow volatility and other explanatory variables pertaining to investment. The results show the percentage change relative to investment per one standard deviation change on the explanatory variable. The negative relationship is robust for the two estimation methodologies the difference and the system GMM and for the two cash flow volatility measures used. "The coefficients estimated range from -0.00035 to -0.203 for the two estimation techniques and measures of cash flow variation. The economic impacts of these results are that for one standard deviation change in cash flow volatility, investment ratio decreases by $-0.0731 \%$ to $-1.3572 \%$ for the four models.

Table 4: Economic Impact of the Regression Estimates

\begin{tabular}{|c|c|c|c|c|}
\hline \multirow[b]{2}{*}{ VARIABLE } & \multicolumn{2}{|c|}{ VOLATILITY = EWMA } & \multicolumn{2}{|c|}{ VOLATILITY $=$ CVCF } \\
\hline & Diff GMM & SYS GMM & DIFF GMM & SYS GMM \\
\hline$C F V 2_{i, c, t}$ & -0.2743 & -0.0731 & & \\
\hline Sales $_{i, c, t} / \mathrm{TA}_{i, c}$ & 0.2141 & 0.2544 & 0.3387 & 0.2046 \\
\hline $\begin{array}{c}Q_{i, c, t} \\
C F V_{i, c, t}\end{array}$ & 0.2114 & 0.1125 & $\begin{array}{l}0.1190 \\
-1.3572\end{array}$ & $\begin{array}{l}0.0527 \\
0.9268\end{array}$ \\
\hline \multicolumn{5}{|c|}{ Economic impact $=\frac{S D_{\text {EXPLANATORY VAR }} \times \text { Regression Coefficient }}{S D_{\text {TEPNDFNTVAR }}}$} \\
\hline
\end{tabular}

Source: Own calculations based on regression results.

The EWMA measure of volatility depicts a higher sensitivity of investment to cash flow variation as shown by higher coefficients $(-0.203$ and -0.0541 compared with -0.000275 and -0.00035 for the coefficients of variation) and higher impact values $-1.3572 \%$ to $0.9268 \%$ compared with $-0.0731 \%$ to $0.2743 \%$. The results imply that cash flow volatility is a key determinant of firm investment in African firms. African firms with more volatile cash flow substantially reduce their investment. The results are in accordance with expectations for African firms' due to many uncertainties in African economies business operations becomes uncertain which makes cash flows as well to be volatile. Firms in such markets will reduce their investment in fear of the unknown and hold more cash and reserves instead for precautionary purposes". In theory, Modigliani and Miller (1958)) hypothesised that firm investment should be unrelated to internally generated cash flows. With respect to this the researchers expected the volatility of cash flows to be unrelated to the investment policy. In spite of this, the evidence against this proposition was found. Cash flows and their volatility exert significant information about investment policy embedded in it. The stability of cash flows is a key determinant of investment in Africa. Cash flows are positively correlated to investment firms that generate more cash flows invest more. The volatility of these cash flows is negatively associated with the investment. African firms with unstable cash flows also reduce investment."

The "negative impact of cash flow volatility on investment can be explained by the fact that high volatility predicts cash flow shortages, firms will hold more cash to counter the shortages, if firms hold more cash investment is foregone. Alternatively, firms in deficit may borrow from the external financial markets which are costlier, affecting investment negatively. The results imply that African firms with higher levels of cash flow uncertainty tend to reduce their investment. African firms should advance their risk management techniques and diversify their portfolios to keep lower leverage levels in order to maintain sustainable cash flows to generate stable cash flows for investment purposes. Higher cash flow volatility will invite borrowing from the external financial market increasing leverage will suppress available cash flows to interest payments constraining investment. Firms should not only focus on generating more cash flows, but the stability of the cash flows has a significant bearing on the investment policy. Stable cash flow generation improves the investment policy of the firm." Consistent with financial theory, firm size as proxied by sales, has a positive 
impact on firm investment. As firms expand they tend to invest more. Growth opportunities, as measured by Tobin's $Q$ have a significant positive impact on investment, and high growth firms have high investment ratios implying higher investment levels compared to low growth firms. The coefficient of the lagged investment variable is statistically significant and positive, implying that previous investment affects the current investment levels and firms with high invest levels tend to invest more in the subsequent periods.

Controlling for Possible Relation between Investment and Cash Flow Levels: To control for a possible relation between cash flow levels and investment, we estimate equation 15 which includes a measure of annual operating cash flows scaled by total assets $\left(O P C F_{i, c, t}\right)$ averaged over the 20 -year sample period as cash flow volatility. Following B. Minton, A, and C. Schrand (1999) a square of operating cash flow variable $\left(O P C F_{i, c, t}^{2}\right)$ which controls for possible non- linearities between average cash flow levels and investment was included. The study also included CFXCFV an interaction of cash flow levels and coefficient of variations which captures the sensitivity of investment to cash flow volatility. Table 2 shows that there is a significant negative correlation between operation cash flows $\left(O P C F_{i, c, t}\right)$ and EWMA cash flow volatility measure (CFV2) with correlation coefficients of -0.115 this relation justifies the use of levels variable in equation 14 for this estimation.

Table 5: Two-Step GMM Possible Relation between Investment and Cash Flow Levels

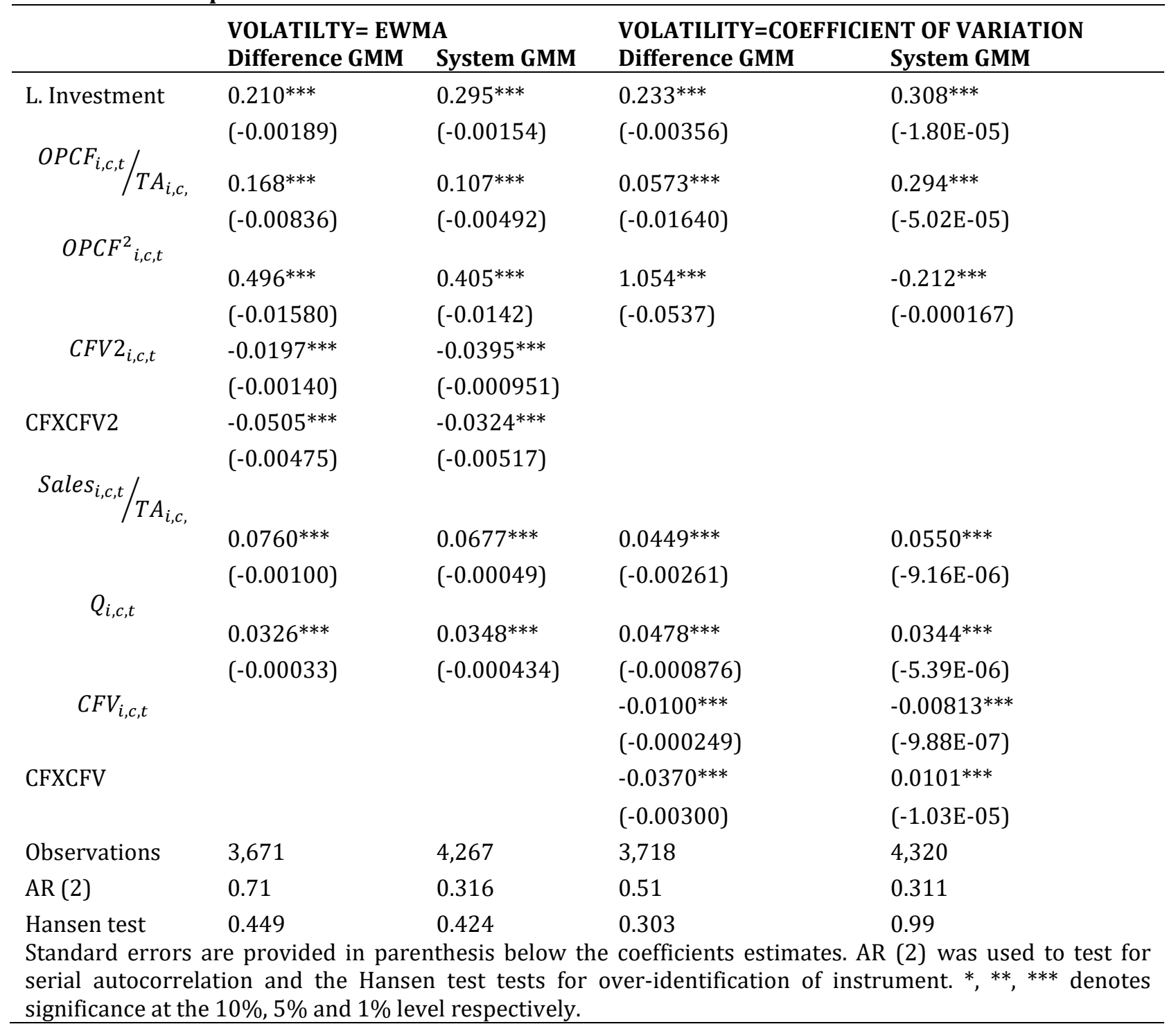


The coefficient of variation measuring of cash flow volatility controls for this mechanical relation between levels and volatility by scaling the standard deviations variable by the absolute mean. Table 5 results indicate that African firms' investment levels are sensitive to operating cash flow volatility, and the sensitivity degree is a function of operating cash flow levels. Including a continuous measure of operating cash flow into the model,it was found that cash flow volatility (for both the two measures of volatility CFV and CFV2) has a negative association with investment. This negative relation is a function of cash flow levels as shown by the positive coefficient of cash flow levels $\left(O P C F_{i, c, t}\right)$ that firms with high cash flow have higher investment levels. The interaction of operating cash flows and cash flow volatility (CFXCVF and CFXCFV2) a measure of the sensitivity of investment to operating cash flows is negative and significant at $1 \%$ level indicating that the sensitivity of investment to cash flow volatility is stronger as cash flows increase. These results are consistent with Minton and Schrand prediction that the influence of volatility is second order relative to the effect of cash flow levels. The negative impact of cash flows volatility on investment is maintained with a regression that controls for the relation between cash flow levels and investment.

Cash Flow Levels and Investment: To establish how African firms respond to cash flow shortages and excess, firstly, capital expenditures of low cash flow firms were examined. In accordance with B. A. Minton and C. Schrand (1999), low cash flow firms were considered based on the difference between a firm's operating cash flows and its average historical cash flows. A negative figure indicates a shortfall position and a positive one will be an excess position. The results in Table 6 indicate that firms experiencing cash flow shortfalls relative to their historical levels are highly sensitive and they have lower levels of investment. Controlling for cash flow shortages in this estimation it was also found that a negative relationship existed between investment and cash flow volatility as shown by the negative coefficients of $C F V 2_{i, c, t}$ (EWMA) and $C F V_{i, c, t}$ (coefficient of variation of cash flows) for models 1 to 4 . Cash flows are a key determinant of investment. Over and above attending to the improvement of cash flows, decision makers should also focus more on cash flow stabilisation. The results provided evidence that cash flow shortages are usually associated with lower investment. As a result, firms experiencing excess cash flows should invest more. Secondly, capital expenditures for firms with excess cash flows were examined. Firms with excess cash flows are those with higher cash flows relative to their historical averages. The coefficient of CFEXCESS is positive and significant at $1 \%$ level.

"As expected, African firms with excess cash flows have higher investment levels. Controlling for firms with excess cash flows the coefficient of the measures of cash flow volatility is significant and negative. These results also indicate that firms with more volatile cash flows have low investment levels even when cash flow shortages and excess are controlled for as shown by the analysis in Table 6. The negative relationship is robust for the two measures of volatility $\left(C F V 2_{i, c, t}\right.$ and $\left.C F V_{i, c, t}\right)$ and the two estimation methodologies used. The research found a positive relationship between cash flows and investment. Firms with excess cash flows invest more and those with cash flow shortages reduce their investment. There is a negative relationship between cash flow volatility and investment. The implication of these findings is that even for firms with excess cash flows, the variability of the cash flows has a constraining effect on investment.

Firms generating high cash flows will also reduce investment if those cash flows are not stable implying that although African firms may aim at generating high cash flows they should pay attention to minimise uncertainty in the cash flows. Not only cash flows but its stability is key to firm investment in African firms. A sensitivity analysis was conducted to determine whether our results are not affected by financial distress. Three different proxies were used for financial distress; financial leverage, interest coverage ratio and fixed assets growth. Firms with a negative average assets growth are considered financially distressed KZ (1997). Consistent with studies of Chikan, Kovacs, and Tátrai (2005), Almeidia et al. (2004) and Acharya and Schaefer (2006), controlling for the possibilities of financial distress, the significance of the association between investment and cash flow volatility holds. The possibility of financial distress cannot explain away the negative relationship between cash flow volatility and investment. 
Table 6: Dynamic Panel Estimation Controlling for Cash Flow Levels

\begin{tabular}{|c|c|c|c|c|c|c|c|c|}
\hline & \multicolumn{4}{|c|}{ CASHFLOW SHORTAGE } & \multicolumn{4}{|c|}{ CASH FLOW EXCESS } \\
\hline & \multicolumn{2}{|c|}{ VOLATILTY= EWMA } & \multicolumn{2}{|c|}{ VOLATILITY=CVCF } & \multicolumn{2}{|c|}{ VOLATILTY= EWMA } & \multicolumn{2}{|c|}{ VOLATILITY=CVCF } \\
\hline & Difference & System & Difference & System & Difference & System & Difference & System \\
\hline & GMM & GMM & GMM & GMM & GMM & GMM & GMM & GMM \\
\hline & (1) & (2) & (3) & (4) & (5) & (6) & (7) & (8) \\
\hline L. Investment & $0.0311^{* *}$ & $0.173^{* * *}$ & $0.208^{* * *}$ & $0.224^{* * *}$ & $0.163^{* * *}$ & $0.258^{* * *}$ & $0.202^{* * *}$ & $0.308^{* * *}$ \\
\hline & $(-0.04090)$ & $(-0.04880)$ & $(-0.00080)$ & $(-0.04430)$ & $(-0.000005)$ & $(-0.00021)$ & $(-0.00701)$ & $(-0.000051)$ \\
\hline $\begin{array}{l}\text { CF- } \\
\text { SHORT/EXCESS }\end{array}$ & $-0.0878^{* * *}$ & $-0.0609^{* * *}$ & $-0.0574^{* * *}$ & $-0.0517^{* * *}$ & $0.0141^{* * *}$ & $0.0711^{* * *}$ & $0.0773^{* * *}$ & $0.0775^{* * *}$ \\
\hline & $(-0.02018)$ & $(-0.02270)$ & $(-0.00050)$ & $(-0.01250)$ & $(-0.00014)$ & $(-0.00033)$ & $(-0.02870)$ & $(-0.00032)$ \\
\hline$O P C F_{i, c, t} / T A_{i, c}$ & $0.513^{* * *}$ & $0.212^{* * *}$ & $0.333^{* * *}$ & $0.244^{* * *}$ & $0.289^{* * *}$ & $0.229^{* * *}$ & $0.615^{* * *}$ & $0.259^{* * *}$ \\
\hline & $(-0.09830)$ & $(-0.04110)$ & $(-0.00190)$ & $(-0.03670)$ & $(-0.00016)$ & $(-0.000093)$ & $(-0.02050)$ & $(-0.000009)$ \\
\hline & $-0.192^{* * *}$ & $-0.0669 * * *$ & & & $-0.129 * * *$ & $-0.0214^{* * *}$ & & \\
\hline & $(-0.04408)$ & $(-0.02380)$ & & & $(-0.00006)$ & $(-0.000049)$ & & \\
\hline & $0.0599 * *$ & $0.0820^{* * *}$ & $0.0680^{* * *}$ & $0.0650^{* * *}$ & $0.0660^{* * *}$ & $0.0820^{* * *}$ & $0.107^{* * *}$ & $0.0853^{* * *}$ \\
\hline & $(-0.02790)$ & $(-0.01140)$ & $(-0.00050)$ & $(-0.01070)$ & $(-0.000054)$ & $(-0.000021)$ & $(-0.00652)$ & $(-0.00003)$ \\
\hline$Q_{i, c, t}$ & & & & & & & & \\
\hline & $0.0526^{* * *}$ & $0.0325^{* * *}$ & $0.0367^{* * *}$ & $0.0296^{* * *}$ & $0.0437^{* * *}$ & $0.0230^{* * *}$ & $0.0466^{* * *}$ & $\begin{array}{l}0.00790^{* * *} \\
(-\end{array}$ \\
\hline & $(-0.01390)$ & $(-0.00970)$ & $(-0.00020)$ & $(-0.00810)$ & $(-0.000025)$ & $(0.00005)$ & $(-0.00418)$ & $0.0000021)$ \\
\hline$C F V_{i, c, t}$ & & & & & & & & - \\
\hline & & & $-0.00420^{* * *}$ & $-0.00971^{* *}$ & & & $-0.00208^{* *}$ & $0.00124^{* * *}$ \\
\hline & & & $(-0.00010)$ & $(-0.00380)$ & & & $(-0.00103)$ & $(-0.000059)$ \\
\hline Observations & 3671 & 4267 & 3718 & 4320 & 3,671 & 4,267 & 3,718 & 4,320 \\
\hline Number of id & 549 & 596 & 557 & 602 & 549 & 596 & 557 & 602 \\
\hline AR (2) & 0.197 & 0.945 & 0.74 & 0.65 & 0.969 & 0.455 & 0.832 & 0.364 \\
\hline Hansen test & 0.598 & 0.457 & 0.243 & 0.366 & 0.984 & 0.465 & 0.539 & 0.983 \\
\hline
\end{tabular}

Cash Flow Volatility and Growth Opportunities: The comprehensive analysis shows that there is a negative relationship between cash flow volatility and investment decisions for African firms. High growth firms are theoretically known for high retention levels associated with high investment levels. Cash flows of these firms are expected to vary more, since they are still in the growth phase and they have higher risks from numerous investment opportunities that they may undertake. The researchers also examined the impact of cash flow volatility on high growth firms. To examine the variances on the impact of cash flow volatility on high- and low-growth opportunity firms, the researchers followed Aivazian et al. (2005). Extending from Equation 10 to include a dummy variable for high- and low-growth firms to interacts with cash flow volatility. Following financial literature, high growth firms were measured as those firms with Tobin's Q greater than 1.

Table 7: High Growth Firms and Cash Flow Volatility

\begin{tabular}{lllll}
\hline & VOLATILTY= EWMA & & \multicolumn{2}{l}{ VOLATILITY=COEFFICIENT OF VAR } \\
& Difference GMM & System GMM & Difference GMM & System GMM \\
\hline L. Investment & $0.0709^{* * *}$ & $0.214^{* * *}$ & $0.153^{* * *}$ & $0.222^{* * *}$ \\
& $-2.16 \mathrm{E}-05$ & $-9.14 \mathrm{E}-05$ & -0.000113 & $-8.26 \mathrm{E}-05$ \\
Q*EWMA & $-0.306^{* * *}$ & $-0.027^{* * *}$ & & \\
& -0.000276 & -0.000151 & & $0.368^{* * *}$ \\
OPCF & $0.345^{* * *}$ & $0.372^{* * *}$ & $0.528^{* * *}$ &
\end{tabular}




\begin{tabular}{lllll} 
& -0.000388 & -0.000349 & -0.000141 & -0.000286 \\
Sales & $0.0845^{* * *}$ & $0.108^{* * *}$ & $0.0924^{* * *}$ & $0.105^{* * *}$ \\
& $-9.06 \mathrm{E}-05$ & $-5.76 \mathrm{E}-05$ & $-5.05 \mathrm{E}-05$ & $-6.06 \mathrm{E}-05$ \\
$\mathrm{Q}$ & $0.0236^{* * *}$ & $0.0032^{* * *}$ & $0.00461^{* * *}$ & $-0.0075^{* * *}$ \\
& $-3.67 \mathrm{E}-05$ & $-2.01 \mathrm{E}-05$ & $-3.63 \mathrm{E}-05$ & $-2.74 \mathrm{E}-05$ \\
$\mathrm{Q}^{*}$ CVCF & & & $-0.00308^{* * *}$ & $-0.001^{* * *}$ \\
& & & $-5.58 \mathrm{E}-06$ & $-8.73 \mathrm{E}-06$ \\
\hline Observations & 2,432 & 2,942 & 2,455 & 2,971 \\
Number of id & 431 & 510 & 436 & 516 \\
Instruments & 402 & 473 & 402 & 365 \\
\hline AR(2) & 0.284 & 0.975 & 0.533 & 0.942 \\
M2 test & 0.832 & 0.981 & 0.857 & 0.42 \\
\hline Th & & &
\end{tabular}

This table provides dynamic panel data estimation results of cash flow volatility on investment on African publicly traded high growth firms. $\mathrm{Q}^{*} \mathrm{CVCF}, \mathrm{Q}^{*} \mathrm{EWMA}$ is an interaction of high growth firms and the two measures of volatility. Standard errors are provided in parenthesis below the coefficients estimates. AR (2) test for serial autocorrelation and the Hansen test, test for over-identification of the instrument. * Significant at the $10 \%$ level. ${ }^{* *}$ Significant at the $5 \%$ level. ${ }^{* * *}$ Significant at the $1 \%$ level

The results in Table 7 indicate that the coefficient of high growth firm's cash flow volatility is negative and significant at one percent level. This shows that the negative relationship between cash flow volatility and investment decisions cannot be explained away by the growth opportunities faced by a firm. The negative relationship between cash flow volatility and investment is still evident even for high growth firms. Considering the elements of corporate cash holdings, Ferreira and Vilela (2004) found that firms with more investment opportunities hold more cash and generate higher cash flows than firms with lower investment opportunities. The implication of the results is that the volatility of cash flows leads to lower investment. This sensitivity analysis shows that the results are not affected by the cross-sectional variation in growth opportunities. Volatility remains a significant negative determinant of investment. The estimation technique used controls for the possible bi-directional relationship through the use of a lagged dependent variable and the use of a system of equations with orthogonal deviations together with an instrumental technique. The results were robust to alternative measures of volatility. The coefficient of variation captures the mechanical relationship between levels and volatility by scaling the standard deviation of the cash flows with the mean absolute value.

The other measure emphasises the importance of the current volatility in calculating average volatility and captures innovations in volatility levels. The results are qualitatively similar. A statistically significant negative relationship between cash flow volatility and investment was found for both high and low cash flow firms suggesting that firms with unstable cash flows tend to reduce their investment. This shows that firms with higher variability in cash flows face greater shortages and would become actively involved with the external financial markets. Unstable cash flows will call for issuing debt or equity in the capital markets. Too much debt will suppress the available cash flows to interest payments while subsequently suppressing investment. Similarly, if firms have unstable cash flows to conceal the shortages they may want to use the equities markets. Firms in need of cash flows can also use the stock markets to finance their investment needs. In trying to generate higher cash flows, firms should aim at maintaining the stability of cash flows and rely more on internally generated funds since debt financing commits firm cash flows to interest payments. African economies should invest in improving the liquidity of the stocks markets to stimulate investment in such economies. 
Model Specification Tests: Testing the legitimacy of instruments and model specification is crucial in dynamic panel data analysis. Using dynamic estimation method controls for endogeneity and heteroscedasticity, however, the differenced equations can produce serial correlation (Baum, 2001). The AB AR (2) test was used to test for the existence of second-order autocorrelation. In all the models, the AR (2) test is above $5 \%$ reject the existence of autocorrelation of order 2 is rejected. The moment conditions should be tested for over-identification (Roodman, 2006), the Hansen-Sargan test as reported in all the models evidence correct identification of instruments. The coefficient of the lagged dependent variable is also less than one which is consistent with dynamic stability. These attest correct specification of our models."

\section{Conclusion}

This article provides evidence on the association between cash flow volatility and firm investment in African firms. There is structural and behavioural heterogeneity between firms in developing and developed economies while analysing African firms on their own is valuable. The analysis employed a unique approach in the form of a dynamic panel model and system GMM which controls for the problem of endogeneity which has not been used in previous studies. This analysis provides direct evidence based on African countries that the volatility of cash flows is associated with lower average investment levels in capital expenditures. The volatility of cash flows remains a significant negative determinant of investment, even after controlling for possible financial distress, the availability of internal funds and growth opportunities. Firms should consider the effects of volatility in their risk management decisions. African firms should trade off the effects of managing volatility and the resulting negative impacts of cash flow volatility on investment levels. This research shows that not only cash flows are a key determinant of investment decisions, but the variability of the cash flows also has a significant bearing on the investment levels of African firms. It was found that cash flow risk as measured by volatility, leads to lower investment even for firms with excess cash flows African firms should not only focus on those strategies to improve cash flow levels, but they should also aim to maintain the stability and reduce the volatility of the cash flows at any given level of operation.

\section{References}

Acharya, V. \& Schaefer, S. (2006). Liquidity risk and correlation risk: Implications for risk management. London, UK London Business School.

Aivazian, V. A., Ge, Y. \& Qiu, J. (2005). The impact of leverage on firm investment: Canadian evidence. Journal of Corporate Finance, 11(1), 277-291.

Akhtar, S. (2005). The determinants of capital structure for Australian multinational and domestic corporations. Australian Journal of management, 30(2), 321-341.

Akhtar, S. \& Oliver, B. (2009). Determinants of capital structure for Japanese multinational and domestic corporations. International review of finance, 9(1-2), 1-26.

Alfaro, L., Chanda, A., Kalemli-Ozcan, S. \& Sayek, S. (2004). FDI and economic growth: the role of local financial markets. Journal of International Economics, 64(1), 89-112.

Allayannis, G. \& Weston, J. P. (2003). Earnings volatility, cashflow volatility, and rm value.

Almeida, H., Campello, M. \& Weisbach, M. S. (2004). The cash flow sensitivity of cash. The Journal of Finance, $59(4), 1777-1804$.

Amo Yartey, C. (2011). Small business finance in Sub-Saharan Africa: the case of Ghana. Management Research Review, 34(2), 172-185.

Anderson, T. W. \& Hsiao, C. (1982). Formulation and estimation of dynamic models using panel data. Journal of Econometrics, 18(1), 47-82.

Antoniou, A., Guney, Y. \& Paudyal, K. (2008). The determinants of capital structure: capital market-oriented versus bank-oriented institutions. Journal of financial and quantitative analysis, 43(01), 59-92.

Arellano, M. \& Bond, S. (1991). Some tests of specification for panel data: Monte Carlo evidence and an application to employment equations. The review of economic studies, 58(2), 277-297.

Bates, T. W. (2005). Asset sales, investment opportunities, and the use of proceeds. The Journal of Finance, 60(1), 105-135.

Baum, C. F., Barkoulas, J. T. \& Caglayan, M. (2001). Nonlinear adjustment to purchasing power parity in the post-Bretton Woods era. Journal of International Money and Finance, 20(3), 379-399. 
Baum, C. F., Caglayan, M. \& Talavera, O. (2009). On the sensitivity of firms' investment to cash flow and uncertainty. Oxford Economic Papers, 62(2), 286-306.

Bigsten, A. \& Söderbom, M. (2006). What have we learned from a decade of manufacturing enterprise surveys in Africa? The World Bank Research Observer, 21(2), 241-265.

Bloom, N., Bond, S. \& Van Reenen, J. (2007). Uncertainty and investment dynamics. The review of economic studies, 74(2), 391-415.

Blundell, R. \& Bond, S. (1998). Initial conditions and moment restrictions in dynamic panel data models. Journal of Econometrics, 87(1), 115-143.

Booth, L., Aivazian, V., Demirguc-Kunt, A. \& Maksimovic, V. (2001). Capital structures in developing countries. The Journal of Finance, 56(1), 87-130.

Booth, L. \& Cleary, S. (2006). Cash flow volatility, financial slack, and investment decisions. Paper presented at the EFMA 2006 Madrid Meetings Paper.

Calcagnini, G. \& Saltari, E. (2000). Real and financial uncertainty and investment decisions. Journal of Macroeconomics, 22(3), 491-514.

Campa, J. \& Goldberg, L. S. (1995). Investment in manufacturing, exchange rates and external exposure. Journal of International Economics, 38(3), 297-320.

Carpenter, R. E., Fazzari, S. M. \& Petersen, B. C. (1998). Financing constraints and inventory investment: A comparative study with high-frequency panel data. Review of Economics and statistics, 80(4), 513519.

Carpenter, R. E. \& Guariglia, A. (2008). Cash flow, investment, and investment opportunities: New tests using UK panel data. Journal of Banking \& Finance, 32(9), 1894-1906.

Chikan, A., Kovacs, E. \& Tátrai, T. (2005). Macroeconomic characteristics and inventory investment: a multicountry study. International Journal of Production Economics, 93, 61-73.

Cleary, S. (2006). International corporate investment and the relationships between financial constraint measures. Journal of Banking \& Finance, 30(5), 1559-1580.

da Costa Moraes, M. B., Nagano, M. S. \& Sobreiro, V. A. (2015). Stochastic cash flow management models: A literature review since the 1980s. In Decision models in engineering and management (pp. 11-28): Springer.

Darby, J., Hallett, A. H., Ireland, J. \& Piscitelli, L. (1999). The impact of exchange rate uncertainty on the level of investment. The Economic Journal, 109(454), 55-67.

DeAngelo, H., DeAngelo, L. \& Stulz, R. (2004). Dividend policy, agency costs, and earned equity. Retrieved from

Donaldson, G. (1963). Financial goals: Management vs. stockholders. Harvard Business Review, 41(3), 116129.

Driver, C. \& Moreton, D. (1991). The influence of uncertainty on UK manufacturing investment. The Economic Journal, 101(409), 1452-1459.

Edmiston, K. D. (2004). Tax Uncertainty and Investment: A Cross-Country Empirical Examination. Economic Inquiry, 42(3), 425-440.

Fazzari, S., Ferri, P. \& Greenberg, E. (2008). Cash flow, investment, and Keynes-Minsky cycles. Journal of Economic Behavior \& Organization, 65(3-4), 555-572.

Fazzari, S. M., Hubbard, R. G., Petersen, B. C., Blinder, A. S. \& Poterba, J. M. (1988). Financing constraints and corporate investment. Brookings papers on economic activity, 1988(1), 141-206.

Ferderer, J. P. (1993). The impact of uncertainty on aggregate investment spending: an empirical analysis. Journal of Money, Credit and Banking, 25(1), 30-48.

Ferreira, M. A. \& Vilela, A. S. (2004). Why do firms hold cash? Evidence from EMU countries. European Financial Management, 10(2), 295-319.

Froot, K. A., Scharfstein, D. S. \& Stein, J. C. (1993). Risk management: Coordinating corporate investment and financing policies. The Journal of Finance, 48(5), 1629-1658.

Geczy, C., Minton, B. \& Schrand, C. (1997). Why rms use currency derivatives?," forthcoming in Journal of Finance.

Géczy, C., Minton, B. A. \& Schrand, C. (1997). Why firms use currency derivatives. The Journal of Finance, 52(4), 1323-1354.

Ghosal, V. \& Loungani, P. (2000). The differential impact of uncertainty on investment in small and large businesses. Review of Economics and statistics, 82(2), 338-343. 
Gilchrist, S. \& Himmelberg, C. P. (1995). Evidence on the role of cash flow for investment. Journal of Monetary Economics, 36(3), 541-572.

Goldberg, L. S. (1993). Exchange rates and investment in United States industry. The Review of Economics and Statistics, 575-588.

Guiso, L. \& Parigi, G. (1999). Investment and demand uncertainty. The Quarterly Journal of Economics, 114(1), 185-227.

Guo, H. (2012). Estimating Volatilities by the GARCH and the EWMA model of PetroChina and TCL in the Stock Exchange Market of China. Paper presented at the 6th International Scientific Conference Managing and Modelling of Financial Risks, VSB-TU Ostrava, Faculty of Economics, Finance Department.(September).

Guoming, A., H. (2009). The cross-section of cashflow volatility and expected stock returns. Journal of Empirical Finance, 16(2009), 409-429.

Gwatidzo, T. \& Ojah, K. (2009). Corporate capital structure determinants: evidence for five African countries. African Finance Journal, 11(1), 1-23.

Hurn, A. S. \& Wright, R. E. (1994). Geology or economics? Testing models of irreversible investment using North Sea oil data. The Economic Journal, 363-371.

Jensen, M. C. (1986). Agency costs of free cash flow, corporate finance, and takeovers. The American economic review, 76(2), 323-329.

Judson, R. A. \& Owen, A. L. (1999). Estimating dynamic panel data models: a guide for macroeconomists. Economics Letters, 65(1), 9-15.

Kester, W. C. (1984). Turning growth options into real assets: Division of Research, Graduate School of Business Administration, Harvard University.

Kovacs, G. (2005). Financing local investments by issuing mu- nicipal bonds. Atalakulasi folyamatok KozepYEuropaban. u: szechenyi Istvan Egyetem Multidiszciplinaris Tarsadalomtudomanyi Doktori Iskola, Gyor, 107-113.

Lang, L., Ofek, E. \& Stulz, R., (1996). Leverage, investment, and firm growth. Journal of Financial Economics, 40(1), 3-29.

Leahy, J. V. \& Whited, T. M. (1995). The effect of uncertainty on investment: Some stylized facts. Retrieved from

Lessard, D. R. \& Lightstone, J. B. (1990). Management of operating exposure. A. Boris (Ed.), Management of Currency Risk, Euromoney Publications, London, 89-96.

Mark, J. F. \& Hankins, W., K. (2012). Estimating dynamic panel models in corporatefinance. Journal of Corporate finance Elsevier, 19(2013), 1-19.

Minton, B., A. \& Schrand, C. (1999). The impact of cash flow volatility on discretionary investment and the costs of debt and equity financing. ELSEVIER.

Minton, B. A. \& Schrand, C. (1999). The impact of cash flow volatility on discretionary investment and the costs of debt and equity financing. Journal of Financial Economics, 54(3), 423-460.

Modigliani, F. \& Miller, M. H. (1958). The cost of capital, corporation finance, and the theory of investment. American Economic Review, 53(3), 433-443

Monga, C. \& Lin, J. Y. (2015). The Oxford Handbook of Africa and Economics: Volume 1: Context and Concepts: OUP Oxford.

Muñoz, F. (2013). Liquidity and firm investment: Evidence for Latin America. Journal of Empirical Finance, 20, 18-29.

Myers, S. C. \& Majluf, N. S. (1984). Corporate financing and investment decisions when firms have information that investors do not have. Journal of financial economics, 13(2), 187-221.

Opler, T., Pinkowitz, L., Stulz, R. \& Williamson, R. (1999). The determinants and implications of corporate cash holdings. Journal of financial economics, 52(1), 3-46.

Riddick, L. A. \& Whited, T. M. (2009). The corporate propensity to save. The Journal of Finance, 64(4), 17291766.

Roodman, D. (2006). How to do xtabond2: An introduction to difference and system GMM in Stata. Center for Global Development working paper, (103).

Servén, L. (2003). Real-exchange-rate uncertainty and private investment in LDCs. The Review of Economics and Statistics, 85(1), 212-218. 
Shapiro, A. \& Titman, S. (1986). An integrated approach to corporate risk management. In: . Basil Blackwell,NewYork.

Shapiro, A. C. \& Titman, S. (1986). An integrated approach to corporate risk management. The revolution in corporate finance, 3, 251-265.

Söderbom, M., Teal, F. \& Wambugu, A. (2005). Unobserved heterogeneity and the relation between earnings and firm size: evidence from two developing countries. Economics Letters, 87(2), 153-159.

Tufano, P. (1996). Who manages risk? An empirical examination of risk management practices in the gold mining industry. The Journal of Finance, 51(4), 1097-1137.

Taylor, J. W. (2004). Volatility forecasting with smooth transition exponential smoothing. International Journal of Forecasting, 20(2), 273-286.

UNCTAD. (2014). World investment report: investing in the SDGs: an action plan.

Yuan, Y. \& Motohashi, K. (2014). Impact of leverage on investment by major shareholders: Evidence from listed firms in China. China Economic Journal, 7(3), 299-319.

Yun, Li., Moutinho, L., Opong, K. K. \& Pang, Y. (2015). Cash flow forecast for South African firms. Review of Development Finance, 5(1), 24-33.

Zamfir, 1. (2016). Growth of Africa. Retrieved from European Parliamentary Research Service 